УДК 663.12

\title{
The effect of complex supplements on $100 \%$ barley malt wort fermentation process
}

\author{
M. Y. ZAYTSEVA ${ }^{1}, P h$. $D$. N. V. BARAKOVA ${ }^{2}$, V. A. ROMANOV ${ }^{3}$ \\ ${ }^{1}$ zaymar225@gmail.com, ${ }^{2}$ n.barakova@mail.ru, ${ }^{3}$ dyvom@notsharingmy.info \\ ITMO University \\ 191002, 9 Lomonosova st., St. Petersburg Russia \\ $P h$. $D$. N. T. ZHILINSKAYA ${ }^{4}$ \\ 4jilinskie@mail.ru \\ Peter the Great Politechnological University's Higher School of Biotechnology and Food Engineering \\ 194021, 48-50 Novorossiyskaya st., St. Petersburg Russia
}

\begin{abstract}
There are multiple important factors in the wort fermentation process, the final gravity of the wort and the total fermentation time being among them. These factors depend on the fermentation activity of yeasts. The fermentation activity in its turn depends on the concentration of nitrogen and minerals in the wort. The effect of two complex supplements, DistilaVite VM and DistilaVite $G N$, on the wort fermentation process was analyzed in this study. The first experiment involved comparing the effect of both supplements on carbon dioxide emission and the biomass gain in $100 \%$ barley malt wort. Another experiment involved comparing the same strain yeast cultures from the wort morphologically. It has been proved that the use of the DistilaVite VM supplement leads to biomass gain increase of up to $44 \%$ and in alcohol yield of up to $2 \%$ compared to the control sample. A rather low value of informational entropy $H(0.012)$, compared to the total informative capacity Hmax (0.5), along with the high redundancy factor $R(97.8 \%)$ shown for the sample with this supplement demonstrate a greater degree of order and a higher level of relative organization for yeast cells of the same strain in the control sample. Therefore, the supplement DistilaVite VM is recommended for obtaining optimal conditions in $100 \%$ barley malt whisky washes.
\end{abstract}

Keywords: complex supplements, fermentation activity, biomass gain, 100\% barley malt wort, nitrogen supplement, yeasts.

Информация о статье

Поступила в редакцию 29.09.2016, принята к печати 09.02.2017

doi: 10.21047/1606-4313-2017-16-1-3-6

Ссылка для цитирования

Zaytseva M. Y., Barakova N. V., Romanov V. A., Zhilinskaya N. T. The effect of complex supplements on $100 \%$ barley malt wort fermentation process // Вестник Международной академии холода. 2017. № 1. С. 3-6.

\section{Влияние комплексных добавок на процесс сбраживания солодового сусла}

\author{
М. Ю. ЗАЙЦЕВА, канд. техн. наук Н. В. БАРАКОВА, В. А. РОМАНОВ \\ Университет ИТМО \\ 191002, Санкт-Петербург, ул. Ломоносова, 9 \\ Канд. биол. наук Н. Т. ЖИЛИНСКАЯ \\ Высшая школа биотехнологии и пищевых технологий СПбПУ \\ 194021, Санкт-Петербург, ул. Новороссийская, 48-50
}

Важными показателями при сбраживании солодового сусла являются степень сбраживания сусла и время брожения. Эти показатели зависят от бродильной активности дрожжей, которая в свою очередь зависит от количества азота и минеральных веществ. Оценивалось действие двух комплексных добавок DistilaVite VM и DistilaVite GN отличного друг от друга состава на процесс сбражсивания солодового сусла. В ходе эксперимента эффективность действия комплексных добавок оценивалась по количеству выделивщегося диоксида углерода и приросту биомассы дрожжей. Также было проведено морфологическое исследование дрожжей и анализ полученной браги. Установлено, что при использовании добавки УМ увеличивается прирост биомассы дрожюжей одинакового итамма до 44\%, а крепость браги - на $2 \%$ об. При применении данной добавки выявлены низкие значения информационной энтропии Н $(0,012)$ относительно значений информационной емкости Нтах $(0,5)$ на фоне высокого значения коэффициента избыточности $R(97,8 \%)$, что характеризует упорядоченность и более высокую степень относительной организации в клетках по сравнению с клетками дрожсжей того жсе штамма, культивируемых без применения комплексной добавки. Использование комплексной добавки УМ рекомендуется для наиболее эффективного сбраживания солодового сусла при производстве виски.

Ключевые слова: комплексные добавки, бродильная активность, прирост биомассы, солодовое сусло, азотистое питание, дрожжи. 
Wort fermentation is one of the essential stages of alcoholic beverage production. The success on this stage largely depends on yeast physiology, including yeast biomass uptake capacity and fermentation activity.

Both factors are affected by fermentation parameters such as temperature, dissolved oxygen concentration, $\mathrm{pH}$ etc., and the content of fermentable sugars, nitrogen, vitamins, macro elements and trace elements in the medium [1].

For both active reproduction and satisfactory fermentation rates, providing attainable nitrogen for yeast cell protein synthesis. Yeasts are capable of consuming multiple organic and inorganic forms of nitrogen $[2,3]$.

Attenuating organic nitrogen (amino acids and amides) requires vitamins in most cases. Providing the medium with metallic ions and mineral anions is also important, these serving as co-factors of various enzymes $[4,5]$.

To introduce the whole multitude of nutrients into the medium, various complex supplements are used. These supplements enhance yeast physiology, biomass uptake and fermentation capacity at the same time [6,7].

The effect of complex supplements on yeast functionality parameters during $100 \%$ barley malt wort fermentation was the scope of the current study.

$100 \%$ barley malt wort (gravity $16.3{ }^{\circ}$ Plato) was used in the experiments. The wort was fermented by DistilaMax MW (Lallemand Biofuels \& Distilled Spirits, France) dry yeast specially designed for malt whisky production. The dosage of the yeast was maintained at $1 \mathrm{~g} \cdot 1^{-1}$ of wort.

The supplements used in the study were DistilaVite VM and DistilaVite GN (Lallemand Biofuels \& Distilled Spirits), both containing inorganic nitrogen (diammonium sulphate), organic nitrogen (free amino acids derived from yeast hydrolysate) and trace elements, while DistilaVite GN is also reported to contain vitamins such as thiamine and niacin by the manufacturer. Both DistilaVite GN и DistilaVite VM dosage was maintained at $0,2 \mathrm{~g} \cdot \mathrm{l}^{-1}$ of wort. The fermentation took 48 hours at $30^{\circ} \mathrm{C}$.

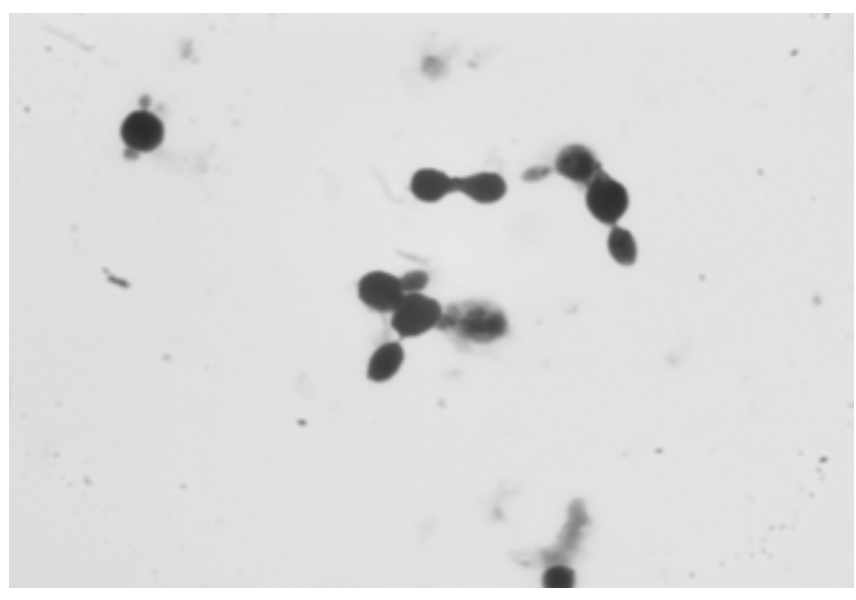

Fig. 1. Yeast cells budding during $100 \%$ malt barley wort attenuation. Methylene blue colouring. Magnification: obj. 100×; ocular $10 \times$

The effectiveness of wort attenuation was assayed by biomass uptake and alcohol content $(\mathrm{v} / \mathrm{v})$ monitoring during fermentation. Goryaiev chamber was used for budding yeast cells and total cells number calculation. Gravimetry was used in assessing carbon dioxide emission capacity via the loss of mass of fermentation vessels.

During and after the fermentation, fixed yeast cell preparations were inspected with an optic Micros MC100 light microscope (Austria) at $400 \times$ or $1000 \times$ magnification to study the changes in morphology. $1 \%$ methylene blue was used for colouring (Fig. 1). Morphometric parameters of individual cells were calculated using the microscope's image recognition software after 48 hours of fermentation. Cell number was extrapolated from the number of budding cells and total cells in 10 randomly selected fields of view at 24, 48 and 72 hours of fermentation (Figs. 2, 3).

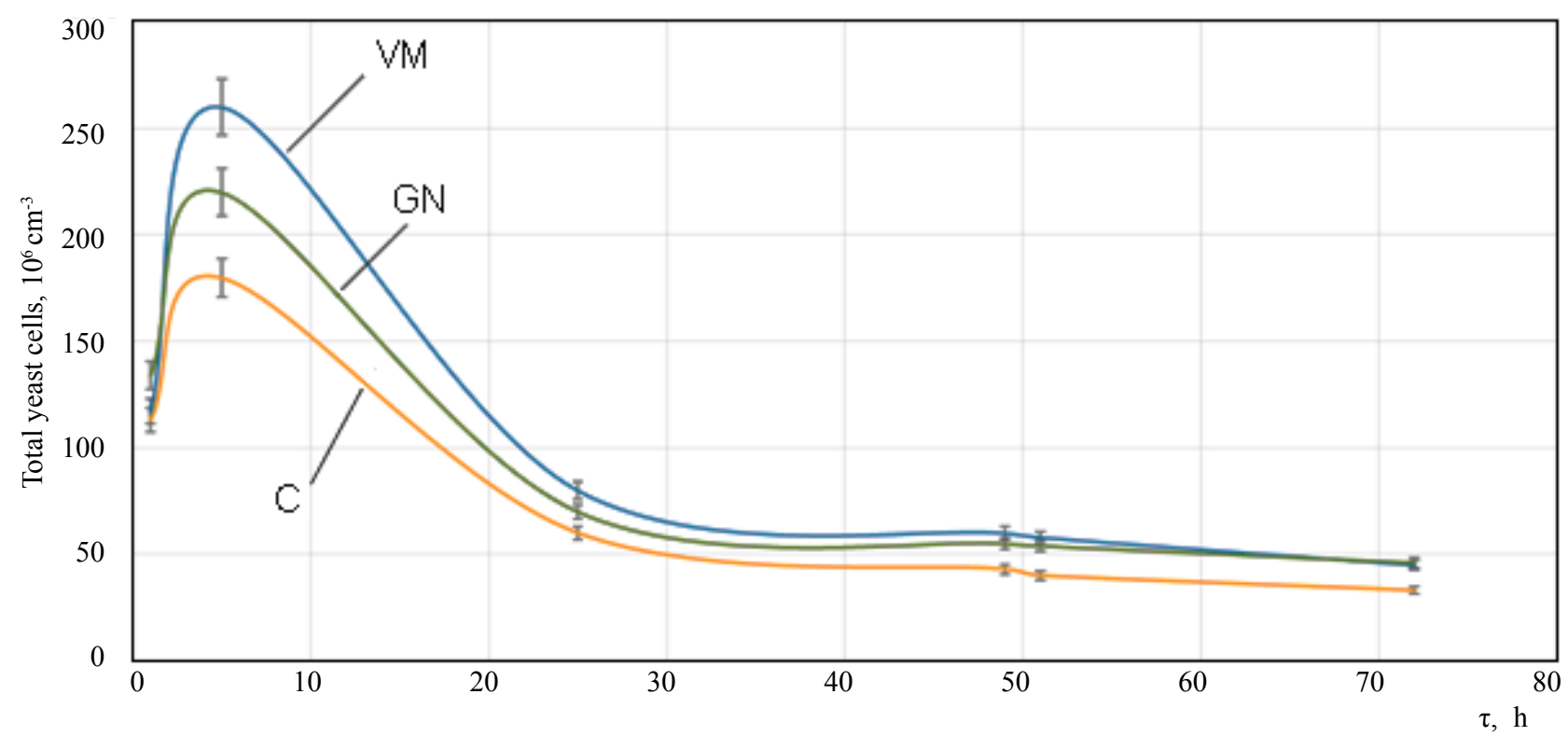

Fig. 2. The dynamic of total yeast cell number change during fermentation 


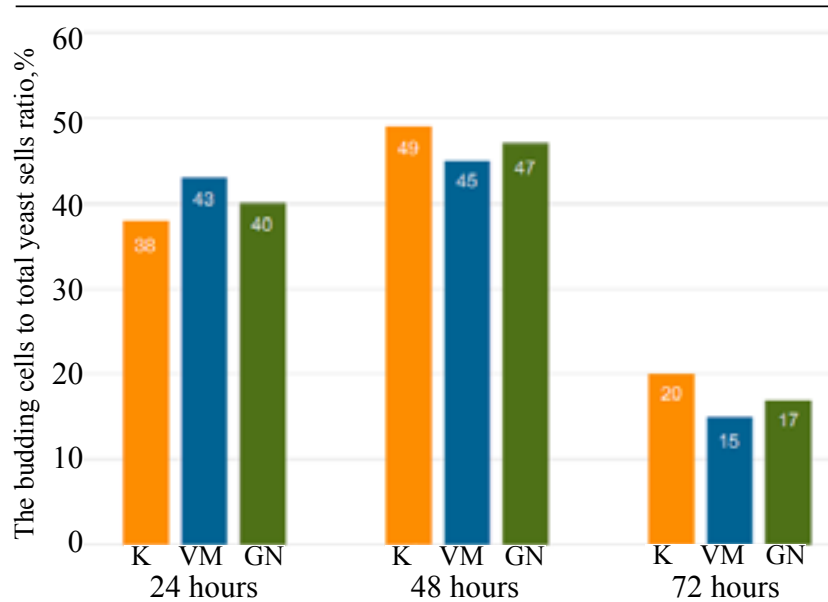

Fig. 3. The impact of budding cell number on the yeast cell total at different points in time. $K-$ control, VM and GN-DistilaMax supplements

Table 1

Bioinformation parameters of DistilaMax MW yeast populations after 48 hours of fermentation

\begin{tabular}{|c|c|c|c|}
\hline & $\begin{array}{c}\text { Informational } \\
\text { enthropy } H\end{array}$ & $\begin{array}{c}\text { Informational } \\
\text { capacity } H_{\max }\end{array}$ & $\begin{array}{c}\text { Redundancy } \\
\text { factor } R, \%\end{array}$ \\
\hline $\begin{array}{c}\text { No supplement } \\
\text { (control) }\end{array}$ & 0.013 & 0.5 & 96.9 \\
\hline $\begin{array}{c}\text { Supplement } \\
\text { DistilaVite GN }\end{array}$ & 0.019 & 0.5 & 97.6 \\
\hline $\begin{array}{c}\text { Supplement } \\
\text { DistilaVite VM }\end{array}$ & 0.012 & 0.5 & 97.8 \\
\hline
\end{tabular}

The data mined as a result of the yeast cell morphometric analysis were used for the calculation of the information parameters of the three yeast populations with a computer program developed earlier [8].

Fig. 4 presents the dynamic of carbon dioxide emission during fermentation.

DistilaMax GN fed yeast population showed a 5\% increase and DistilaMax VM fed population a $13 \%$ increase in budding cell numbers after 24 hours of fermentation as compared to the control sample. After 46 hours, the budding yeast percentage started falling in all samples, yet populations supplied with both DistilaMax VM and DistilaMax GN demonstrated less rapid falls of the respective percentages (Fig. 3).

Yeast biomass gain during fermentation is another essential factor of cell physiology evaluation. The curve imaging the dynamic of DistilaMax VM fed yeast biomass gain in Fig. 2 shows a 44\% increase in cell biomass after 5 hours of fermentation as compared to the control sample.

The yeast populations development curves shown in Figs. 2 and 3 demonstrate normal yeast population growth and detriment dynamics believed to be based on the limit to cell budding and the alcohol-induced stress [9-11]. This can be also proven true by the dynamic of carbon dioxide emission evaluation (Fig. 4).

Additionally, the following information parameters of the populations were calculated using cell morphometry data:

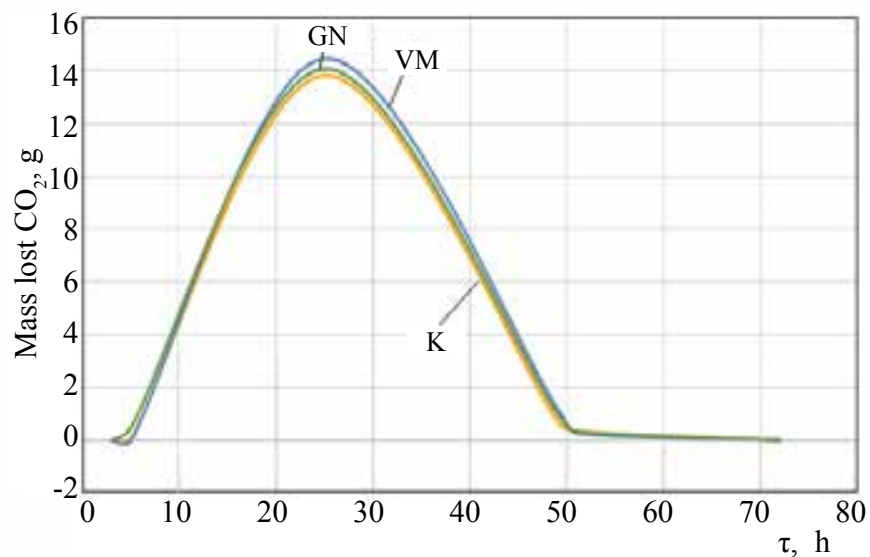

Fig. 4. The dynamic of carbon dioxide emission during fermentation. $K$ - control, VM and GN-DistilaMax supplements

Table 2

Principal physical and chemical parameters of the fermented wash

\begin{tabular}{|c|c|c|c|}
\hline & $\mathrm{pH}$ & $\begin{array}{c}\text { Alcohol content } \\
(10 \% \mathrm{v} / \mathrm{v})\end{array}$ & Alcohol yield, $\mathrm{ml}$ \\
\hline $\begin{array}{c}\text { No supple- } \\
\text { ment (con- } \\
\text { trol) }\end{array}$ & 3.7 & 8 & 66.6 \\
\hline $\begin{array}{c}\text { Supplement } \\
\text { DistilaVite } \\
\text { GN }\end{array}$ & 4.1 & 10 & 74.8 \\
\hline $\begin{array}{c}\text { Supplement } \\
\text { DistilaVite } \\
\text { VM }\end{array}$ & 4.3 & 9 & 70.8 \\
\hline
\end{tabular}

informational entropy $H$, a (originally thermodynamic) variable characterizing the informative responsiveness of the system; total informative capacity $H_{\text {max }}$; system redundancy factor $R(\%)$, a measure of the informative robustness of the system. The values $H, H_{\max }$ and $R$ obtained for the three populations of DistilaMax MW at 48 hours of fermentation are shown in Table 1.

In the control sample, the redundancy factor $R$ was found to be $96.9 \%$; in the sample provided with the supplement DistilaVite GN 97.6\%; in the third sample the redundancy factor was $97.8 \%$.

The third sample also demonstrates a rather low value of informational entropy $H(0.012)$, compared to the total informative capacity $H_{\max }$ value of 0.5 and the high value of the redundancy factor $R(97.8 \%)$ in the sample with the supplement VM demonstrate a greater degree of order and relative organization of yeast cells of the same strain in the control sample.

The principal physical and chemical parameters of the fermented wash in the three samples were assessed after the fermentation. The parameters are shown in Table 2.

As shown in Table 2, the highest alcohol content $(10 \% \mathrm{v} / \mathrm{v})$ was found in the sample provided with the supplement DistilaVite VM. The supplement DistilaVite VM is therefore recommended for obtaining optimal conditions in $100 \%$ barley malt whisky washes. 


\section{References}

1. Римарева Л. В. Теоретические и практические основы биотехнологии дрожжей. - М.: ДеЛи принт, 2010. С. 99-108. [Rimaryova L. V. Theoretical and practical foundations of yeast biotechnology. Moscow, DeLi Print, 2010. p. 99-108. (in Russian)]

2. Dilip K. Arora. Fungal Biotechnology in Agricultural, Food, and Environmental Applications. - Marcel Dekker, 2004. 365 p.

3. Inge Russell. Whisky: Technology, Production and Marketing. Elsevier, 2003. 349 p.

4. Chris White, Jamil Zainasheff. Yeast: the Practical Guide to Beer Fermentation. - Brewers Publications, 2010. 13 p.

5. Макаров С. Ю. Основы технологии виски. - М.: Космос, 2011. 76 c. [Makarov S. Yu. Basics of whiskey production. Moscow, Kosmos, 2011. 76 p. (in Russian)]

6. Меледина Т. В. Сырье и вспомогательные материалы в пивоварении. - СПб.: Профессия, 2003. 304 с. [Meledina T. V. Raw and auxiliary materials in brewing. St. Petersburg, Professiya, 2003. 304 p. (in Russian)]

7. Магомедов Г. О., Кочетов В. К., Смирных А. А., Саранов И. А. Исследование динамической вязкости концентратов ячменного солода и цикория. // Вестник Воронежского государственного университета инженерных технологий. 2016; (3):11-17. DOI:10.20914/2310-1202-2016-3-11-17 [Magomedov G. O., Kochetov V. K., Smirnykh A. A., Saranov I. A. Dynamic viscosity study of barley malt and chicory concentrates. Proceedings of the Voronezh State University of Engineering Technologies. 2016; (3):11-17. (in Russian)]

8. Жилинская Н. Т., Шлейкин А. Г., Хамидова Д. Н. применение методов информационно-морфометрического анализа при исследовании микроорганизмов - продуцентов биотехнологических продуктов. Материалы VII МНПК «Низкотемпературные и пищевые технологии в XXI веке» (17 ноября - 20 ноября 2015, С-Петербург), 2015. Часть 2. с. 272-276. [Zhilinskaya N. T., Shleikin A. G., Khamidova D. N. Application of information and morphometric analysis to studying microorganisms for biotechnology. Proceedings of the VII International Pure and Applied Science Conference "Refrigeration and Food Engineering in the 21st century" (November 17 - November 20, 2015, St.Petersburg). 2015. No 2. P. 272-276. (in Russian)]

9. Меледина Т. В., Давыденко С. Г., Васильева Л. М. Физиологическое состояние дрожжей. СПб.: Университет ITMO, 2013. 48 p. [Meledina T. V., Davydenko S. G., Vasilyeva L. M. Assessing Yeast Physiology: a Manual. St.-Petersburg, ITMO University, 2013. 48 p. (in Russian)]

10. Шлейкин А. Г., Жилинская Н. Т. Введение в Биотехнологию: Учебник. СПб.: Университет ITMO, 2013. p 11-45. [Shleykin A. G., Zhilinskaya N. T. An Introduction to Biotechnology: a Textbook. St.-Petersburg, ITMO University, 2013. p 11-45. (in Russian)]

11. Автандилов Г. Г. Медицинская морфометрия. - М.: Медицина, 1990. с. 139-149. [Avtandilov G. G. Medical morphometry. Moscow, Mieditsina, 1990. P. 139-149. (in Russian)]

\section{VIII международная научно-техническая конференция «Низкотемпературные и пищевые технологии в XXI веке» УНИВЕРСИТЕТ ИТМО

\author{
ОРГАНИЗАТОРЫ: \\ УНИВЕРСИТЕТ ИТМО \\ МЕЖДУНАРОДНАЯ АКАДЕМИЯ ХОЛОДА
}

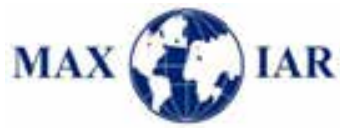

\section{5 - 17 ноября 2017}

Конференция проводится на базе мегафакультета биотехнологий и низкотемпературных систем Университета ИТМО по адресу: 191002, Санкт-Петербург, ул. Ломоносова, 9

\section{ОСНОВНЫЕ НАУЧНЫЕ НАПРАВЛЕНИЯ КОНФЕРЕНЦИИ:}

$>$ Низкотемпературная техника и системы

низкопотенциальной энергетики;

$>$ Надежность материалов оборудования

биотехнологий и низкотемпературных систем;

$>$ Автоматизация процессов и устройств;

$>$ Криогенная техника и технологии СПг;

$>$ Системы кондиционирования и жизнеобеспечения;
$>$ Теоретические основы тепло- и хладотехники;

$>$ Техника и процессы пищевых производств;

$>$ Пищевые технологии. Биотехнологии;

$>$ Химический инжиниринг;

$>$ Промышленная экология и техносферная безопасность;

$>$ Экономика и управление производством.

Срок подачи заявок до 1 июня 2017 г., срок сдачи докладов до 15 июня 2017 г.

Телефон для справок: (812) 572-27-10, Платунова Яна Яковлевна

E-mail: rft21@corp.ifmo.ru 